Мср Милица В. Ћуковић

\author{
„ПОСЛАНСТВО“ ЛЕТОПИСА МАТИЦЕ СРПСКЕ \\ У СОФИЈИ И РИМУ: ПИСМА ЈОВАНА ДУЧИЋА \\ ТИХОМИРУ ОСТОЈИЋУ
}

\begin{abstract}
У раду су приређена и прокоментарисана писма и дописнице које је Јован Дучић послао Тихомиру Остојићу, у периоду од 1903. до 1914. године, из Швајцарске, Бугарске, Грчке и Италије. Ова писма и дописнице, који се чувају у Рукописном одељењу Матице српске, пружају податке о лепом, непомућеном, дугогодишњем пријатељству између Јована Дучића и Тихомира Остојића, она садрже релевантне и занимљиве Дучићеве аутопоетичке исказе, а више од свега, ова писма и дописнице сведочанство су труда, енергије и посвећености којима је Дучић приступио сарадњи на Летиоиису Майице срйске у време уређивања Тихомира Остојића, када је Дучић био готово спољни члан редакције овог часописа.

Кључне речи: Јован Дучић, Тихомир Остојић, писма, Лет̄ойис Майице срииске.
\end{abstract}

Српски песник, прозни писац, есејиста, путописац, један од покретача (1896), а потом члан редакцијског одбора (1898) и уредник (1899) мостарског књижевног часописа Зора, сарадник, потом уредник културне хронике (1908) у Политииич, дописни (1924), затим и редовни (1931) члан Српске краљевске академије (данашње Српске академије наука и уметности) ${ }^{1}$, Јован Дучић остварио је богату дипломатску каријеру. Како запажа приређивач Дийломайских сйиса Јована Дучића, Миладин Милошевић „Јован Дучић био је у дипломатији 31 годину, 1910-1941. (...) Службовао је у девет држава у којима

${ }^{1}$ Како наводи Иван Негришорац, Јован Дучић „За дописног члана СКА изабран је 18. фебруара 1924, а тих дана га је лондонски ПЕН изабрао за почасног члана за Србију. (...) За редовног члана СКА изабран је 16. фебруара 1931.“Видети: И. Негришорац, „Дучић, Јован“, у: Срйски биоірафски речник, књ. 3, Д-3, главни уредник Чедомир Попов, уредници Злата Бојовић и др., Матица српска, Нови Сад, 2007, стр. 462-463. 
је био у тринаест мисија. Био је шеф мисије у шест држава. (...) Први је у историји југословенске дипломатије именован у звање амбасадора, чиме му је указано поверење и част и као великом писцу и као успешном дипломати. Целокупна његова дипломатска каријера везана је за рад у мисијама у иностранству.“2 Своју дипломатску каријеру, која је подразумевала рад у ,...Софији, Риму, Атини, Мадриду, поново Атини, Женеви, Каиру, Будимпешти, поново у Риму, Букурешту на крају опет у Мадриду..."3, односно напредовање у звањима ,...од писара посланства преко секретара, саветника, генералног конзула, отправника послова, посланика до амбасадора, првог са тим звањем у Краљевини Југославији“ (Исто), Јован Дучић започео је, краљевским указом од 10. маја 1910. године, ,...као писар прве класе (прескочивши звање писара III и II класе) Српског краљевског посланства у Софији“ (Исто: 9). Након боравка и рада у главном граду Бугарске, Јован Дучић „,..краљевским указом од 29. јуна 1912. унапређен [je] у звање секретара $V$ класе Посланства КС у Риму“ (Исто: 10), при чему „У Рим је стигао почетком августа 1912. године у предвечерје Првог балканског рата и одмах се ангажује на задобијању италијанске јавности да прихвати чињеницу да је рат против Турске једини излаз из кризе. Тај његов рад нарочито се манифестовао писањем у италијанском листу 'Трибуна', о чему је октобра 1912. известио свог пријатеља Ј. Јовановића, начелника МИД-а“ (Исто). ${ }^{4}$

У Рукописном одељењу Матице српске налази се шест писама и шест дописница које је Јован Дучић послао Тихомиру Остојићу, у периоду од 1903. до 1914. године, из Швајцарске, Италије, Грчке и Бугарске. Са изузетком првог писма, из 1903. године, које је било интимне природе, сачувана писма и дописнице Јована Дучића махом су везана за период у којем је Јован Дучић обављао функцију писара Српског краљевског посланства у Софији,

${ }^{2}$ Миладин Милошевић, „Српски писци у дипломатији Краљевине Србије и Краљевине Југославије“, у: Два века модерне срйске gийломайије, ур. Чедомир Попов, Драгољуб Р. Живојиновић и Слободан Г. Марковић, Балканолошки институт САНУ, Београд, 2015, стр. 198-199.

${ }^{3}$ Миладин Милошевић, [Предговор], у: Јован Дучић, Дийломайски сйиси, приредио, предговор и коментаре написао Миладин Милошевић, Просвета, Београд, 1991, стр. 26.

${ }^{4}$ Иван Негришорац, у Срйском биоірафском речнику, у свега неколико реченица прецизно резимира разгранату дипломатску активност Јована Дучића у Софији и Риму „Краљевим указом од 10. маја 1910, као писар прве класе (прескочивши звање писара треће и друге класе) и после кратког рада у Цариграду, постављен је у српско посланство у Софији. Из Софије се, премда ниског звања, а по сугестији посланика Светислава Симића, јавио писмом министру Миловану Миловановићу са подробном анализом карактера и политичких ставова бугарског краља Фердинанда. Краљевим указом од 29. јуна 1912. постављен је за секретара пете класе Српског краљевског посланства у Риму, где је у то време отправник послова, а касније и посланик био Љубомир Михаиловић. Дучић је развио јаку пропагандну активност, објављујући текстове и дајући интервјуе у италијанској штампи, а све са циљем да се јавности објасни неопходност рата са Турском.“ Видети: И. Негришорац, „Дучић, Јован“, у: Срйски биоірафски речник, књ. 3, Д-3, главни уредник Чедомир Попов, уредници Злата Бојовић и др., Матица српска, Нови Сад, 2007, стр. 462. 
односно секретара посланства Краљевине Југославије у Риму, а Тихомир Остојић функцију секретара Матице српске и уредника Летиойиса Майице срйске, дакле за период од 1912. до 1914. године, а у свим овим писмима и дописницама средишња и најважнија тема пријатељског дописивања је Лейойис Майице срйске. По обиму и броју невелика, писма Јована Дучића Тихомиру Остојићу изузетно су драгоцена, са неколико аспеката: књижевноисторијског (ова писма сведоче у којој је мери и на који начин Јован Дучић био везан за Лейойис Майище срйске, чиме је, уједно, пружена могућност да се исправе или прецизирају неке од раније изнетих тврдњи, о сарадњи Јована Дучића у Летиоиису Майиие срйске, у време када је овај часопис уређивао Тихомир Остојић), аутопоетичког (у писмима се могу наћи изјаве Јована Дучића о његовом односу према препевима и преводима, или о начину на који је овај књижевник писао), као и са аспекта разумевања карактера Јована Дучића (из ових писама и дописница могу се реконструисати контуре портрета Јована Дучића као пријатеља, али и као сарадника часописа).

И поред редовног писања и слања месечних извештаја Министарству иностраних дела Краљевине Србије, Јован Дучић, током боравка у Софији и Риму, не запоставља ни књижевност. Тако, како сазнајемо из сачуваних писама и дописница упућених Тихомиру Остојићу, Јован Дучић указује се као неко ко редовно чита српске часописе (конкретно, Лейойис Майице срииске), неко ко коментарише уметничку вредност објављених прилога, неко ко предлаже сараднике или се чуди због заступљености писаца које не сматра талентованима: „Зашто у овој свесци нема Вељка Петровића и Васе Стајића? Прока Јовкић није за Летопис. Обрати се Ћипику (Београд).“ (РОМС, инв. бр. 4. 916). Указује се као неко ко уверава српске писце са колико се посвећености, одговорности и љубави према српској књижевности Тихомир Остојић прихватио места уредника Летиойиса Майище срйске. Бележи: „Ја сам ономад у Београду говорио с многим млађим добрим пријатељима да треба да Летопис сматрају својом ствари јер знам колико његов уредник ставља у њега амбиције, патриотизма и сујете“ (РОМС, инв. бр. 4. 919), или „Ја сам решен да ти будем од користи на Летопису. Надам се да ћу неке пријатеље задобити да узму Летопис као своје лично питање и обавезу“ (РОМС, инв. бр. 4. 912), чиме је Јован Дучић, према запажањима Миливоја Ненина, заузео готово позицију спољног члана редакције Лейойиса Майище срйске: „Он је готово члан редакције (истина, спољни!); он агитује, организује, прикупља сараднике. Тражи од писаца да шаљу прилоге Тихомиру Остојићу - уверавајући их са колико је енергије и Остојић приступио том уредничком послу““5 За разлику од Проке Јовкића, којег Јован Дучић није ценио и о чијем је стваралаштву изрекао недвосмислено негативан и изразито суров суд, одређујући Јовкића као писца коме уопште није место у Лейойису Майище срииске, дотле je, с друге стране, Јован Дучић заслужан за увођење Тодора Манојловића у

${ }^{5}$ Видети: Миливој Ненин, Писма Јована Дучића Тихомиру Остојићу, у: Сви моји банайски йисии: йриказе и йрикази, Банатски културни центар, Ново Милошево, 2016, стр. 83. 
српску књижевност. Препознавши књижевнокритички дар Тодора Манојловића, Дучић је препоручио овог аутора Тихомиру Остојићу, са̂м је Манојловићу исплатио хонорар (тек касније узевши новац од Тихомира Остојића), пропративши и објављивање Манојловићевог текста у Лейойису Майище срйске: „Јован Дучић је био тај који је наручио текстове од Тодора Манојловића, иако овај пре тога није имао објављен ниједан критички текст на српском језику! Уистину се понашао као спољни члан редакције, али и много више од тога. Не само што је Манојловићеве текстове испратио; већ је посао уредника довео до краја. Наиме, из свог џепа (све то знамо из ових писама!) дао је хонорар Тодору Манојловићу - овај је путовао у Напуљ и био му је важан сваки динар. (Тек после је Дучић од Тихомира Остојића добио свој новац). Умало да заборавим да кажем - Дучић је Манојловићев текст и опремио за штампу“ (Исто: 85), као што је, исто тако, Јован Дучић умео да похвали свог покојног колегу песника Пенча Славејкова и да изрекне више него афирмативан суд о његовој поезији, коју је чак, за Летиойис Мат̄ище срииске, превео и опремио биографским и есејистичким Post scriptum-ом: „Сутра ћу ти послати и серију песама Пенча Славејкова у елегантној прози (...) Послаћу ти и биографију с оценом његове поезије. Тај чланчић би изишао ситнијим словима као Post scriptum тих превода. (...) Послаћу ти десет песама најлепших и најкарактеристичнијих за његов лепи таленат“ (РОМС, инв. бр. 4. 919). Поред тражења сарадника̂ за Лет̄ойис Майище срйске Тихомира Остојића, Јован Дучић јавио се у Летиойису и као аутор, објавивши обиман есеј о Петру Кочићу „За два три дана - чим будем све преписао начисто - добићеш мој рукопис. Шаљем ти један свој есеј (40 страна рукописа) о Петру Кочићу из књиге есеја који ће изићи до јесени. Надам се да ћеш бити задовољан“ (РОМС, инв. бр. 4. 912) ${ }^{6}$. Ипак, иако је у Лейойису Майице срйске у време уређивања Тихомира Остојића Јован Дучић објавио један једини текст - „Књижевни есеј“ о Петру Кочићу - Дучић је Остојићу непрекидно обећавао да ће му послати радове. Он пише: „Драги мој Остојићу, ево мој први рад за твој Летопис. Надам се да ћеш бити задовољан и уверен колико желим напретка твом листу“ (РОМС, инв. бр. 4. 919), „Драги Тихомире, сутра ћеш добити један пакет рукописа за Летопис“( РОМС, инв. бр. 4. 918), „Извини што ти још ништа не шаљем. Ја сам са̂м. Али ћу стићи, надам се, за број који је на реду“ (РОМС, инв. бр. 4. 908), „Спремам ти један рад за Летопис, али ти нећу одмах моћи свршити јер сам овде у грдном послу (позван сам из Рима депешом)“ (РОМС, инв. бр. 4. 913) и „Мили Тихомире, ако је Летопис с мојим есејом већ изишао, молим те пошаљи га у Рим, куда одлазим данас. Прво што напишем биће опет за тебе“ (РОМС, инв. бр. 4. 914). Дучићев труд око прикупљања квалитетних сарадника за Лейойис Майице срйске, слање својих текстова и непрестана уверавања о текстовима које пише и које ће тек послати Остојићу, сведоче о савесности, брижљивости и пожртвованости,

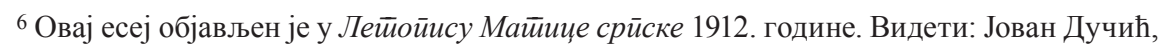
Петар Кочић: књижевни есеј, Летиойис Майице срйске, год. 87, књ. 288, св. 4, 1912, стр. 70-88. 
о великој енергији и вољи коју је Јован Дучић уложио у Лейойис Майице срйске у време када овај часопис уређује Тихомир Остојић. Дучићева писма лепо су и искрено сведочанство о неизмерном труду и једном великом старању Јована Дучића око квалитета књижевних прилога Лет̄ойиса Майице срииске, а уједно, у овим писмима може се наћи и доказ о бризи префињеног естете (какав је био Дучић) о спољашњој опреми часописа - тако, у писму од 10. априла 1912. године Јован Дучић обавештава Тихомира Остојића како је наручио једну свеску неке књижевне ревије ,...чија је опрема угледна и вредна да се узме за образац“ (РОМС, инв. бр. 4. 915) и како би радо обавестио Остојића о опреми дотичне ревије, која би могла да послужи као узор за техничко уређење Лет̄ойиса Майице срйске. С друге стране, о Дучићевом перфекционизму, вођењу рачуна о детаљима и бризи о појединостима сведоче и услови под којима је Дучић сарађивао у Летиойису Майице срйске, а које је овај писац отворено саопштио Тихомиру Остојићу. Наиме, Дучић захтева да он саิм води коректуру својих текстова и да му радови буду објављени на месту које заслужује он као писац и његови радови као квалитетна уметничка остварења: „Само, драги Тихомире, два мала услова: 1) да не изиђе рад на неугледном месту, и 2) да ја водим коректуру“ (РОМС, инв. бр. 4. 919), односно, да уредно добија Летиойис Майище срйске. Бележи: „Али ако желиш да не сметнем с ума, и да поверујем да држиш до моје сарадње, шаљи ми Летопис. Нас нема много који пишемо и који треба да буду заједно у Летопису, и зато лист мора чинити ту жртву - можда не и без свог интереса“"(РОМС, инв. бр. 4. 915). Имајући у виду залагање Јована Дучића око Лейойиса Майище срииске, његов рад на придобијању сарадника, старање и о техничкој опреми овог часописа, не изненађује Дучићева изјава, изнета у дописници, 4. децембра 1913. године, како „Пашић не би разумео да смо ми овде и посланство нашег Летописа“ (РОМС, инв. бр. 4. 908).

С друге стране, писма и дописнице које је Јован Дучић послао Тихомиру Остојићу пружају прилику за прецизније сагледавање улоге Јована Дучића у Летиоиису Матиице срйске, као и за кориговање тврдњи изнетих поводом Дучићеве сарадње у Остојићевом Летиоиису. Наиме, Иванка Удовички, у раду Траяиционализам и моgернизам у Осйојићевом Летопису ${ }^{7}$ истакла је како се у време када Тихомир Остојић уређује Лейойис Майице срйске из овог часописа повлаче књижевни критичари, историчари књижевности и писци који су раније (у Летиойису Милана Савића) били стални сарадници. Међу писцима који су смањили обим сарадње у Летиойису Майице срйске Иванка Удовички навела је Јована Дучића „Неки су се сарадници повукли, а неки сасвим сузили своју сарадњу. Дучић у овом часопису поезију више не објављује, али је дао још леп есеј о Петру Кочићу (књ. 288)“

${ }^{7}$ Иванка Удовички, „Традиционализам и модернизам у Остојићевом Лет̄ойису“, у: Траяиционално и модерно у срйским часоиичсима на йочейку века (1895-1914), зборник раgова, уреднице Слободанка Пековић и Весна Матовић, Институт за књижевност и уметност, Београд, Матица српска, Нови Сад, 1992, стр. 37-39. 
(Исто: 37). Упркос томе што је тврдња коју је Иванка Удовички изнела поводом Дучићеве сарадње у Лейойису Майиие срйске у периоду од 1912. до 1914. године тачна, она није у потпуности прецизна, будући да је смањење сарадње Јована Дучића у Лейойису Майице срйске највероватније последица недостатка времена, а не намерна жеља да се обим сарадње смањи. Напротив, као што се јасно види из писама и дописница које је послао Тихомиру Остојићу, Јован Дучић уложио је много времена, енергије и труда у Летиойис Майице срииске, како као спољни члан редакције, тако и као сарадник овог часописа (упркос томе што је у наведеном периоду објавио један једини прилог у Лейойису Майице срйске, Јован Дучић обећавао је уреднику да ће послати још текстова, планирао је да пише за Лейойис Мa-

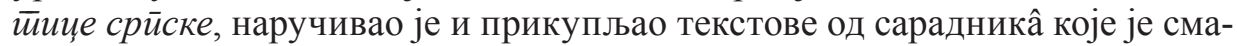
трао добрим писцима). Закључак о смањењу сарадње Јована Дучића у Лейойису Майище срйске у периоду од 1912. до 1914. године није нетачан, али писма која је Јован Дучић послао Тихомиру Остојићу дају могућност да се овај закључак коригује и да се обим Дучићеве сарадње у Остојићевом Ле$\bar{u} о \bar{u} и c y$ прецизније сагледа и да се суд о овој сарадњи донекле ревидира.

Поред података о старању Јована Дучића за Летиойис Майице срйске, у овим писмима и дописницама садржани су и аутопоетички искази Јована Дучића о природи властитог стваралачког поступка, као и о односу према преводима и препевима поезије на српски језик. Тако, у писму послатом Остојићу 1912. године из Софије, поводом свог превода поезије Пенча Славејкова, Јован Дучић истиче да је поезију овог аутора превео „...у елегантној прози (јер ја сам против препевавања које увек убије оригинал својим врлинама или својим манама), а тако преводе и Енглези и Французи“ (РОМС, инв. бр. 4. 919). С друге стране, у истом писму, шаљући свој први текст за Остојићев Лейойис Майице срйске, Јован Дучић оставио је драгоцено сведочанство о начину на који он са̂м пише „Опрости што овај есеј не послах пре. Ти не знаш каква сам цепидлака у писању и колико се порађам кад пишем само да се после не бих покајао за оно што кажем и како кажем“ (РОМС, инв. бр. 4. 919).

Коначно, Дучићева писма и дописнице сведочанство су блискости, поверења и дугогодишњег лепог пријатељства између Јована Дучића и Тихомира Остојића. О степену поверења између ове двојице књижевника, о разговорима како о књижевним тако и о интимним плановима, о блискости и разумевању које је било снажно и непомућено, у великој мери говори и Дучићево писмо из 1903. године (РОМС, инв. бр. 4. 909), у којем је реч о питању интимне природе и услузи коју је од Остојића затражио Јован Дучић. О блискости између Јована Дучића и Тихомира Остојића, поред молбе интимне природе, сведочи и Дучићево отворено, искрено и експлицитно изношење вредносних судова о прилозима објављеним у Летиойису Майище срйске, а уједно и начин на који се Дучић у писмима обраћао Тихомиру Остојићу. Јован Дучић ословљавао је Остојића на следеће начине: „Мили мој Тихомире“, „Драги мој Тихомире“, „Мили Тихомире“, „Драги Тихомире“, 
„Драги мој Остојићу“, као што је писма и дописнице најчешће завршавао на идентичан начин, речима - „срдачно твој увек“. Поред доказа о искреном пријатељству и непрекинутој, ничим помућеној, срдачној и лепој књижевној сарадњи између Јована Дучића и Тихомира Остојића, Дучићева писма и дописнице упућене Тихомиру Остојићу садрже и доказе о Дучићевом залагању за младе колеге код којих је препознао књижевни таленат (срдачна препорука и залагање за Тодора Манојловића), о похвалном говору и комплиментима које је без имало сујете умео да изрекне о нечијој поезији (о поезији Пенча Славејкова), али и доказе о приоритетима Јована Дучића. Неко ко је свој тестамент из 1941. године завршио својим аутопортретом, оставивши слику себе као ,...патриоте, којем је и у задњем часу лебдио пред очима тешки положај Српства у збрци појмова и противуречних идеја у којима се оно налази овог момента.“" сланства Краљевине Србије у Софији и секретар пете класе Српског краљевског посланства у Риму, као властити приоритет посматрао своју сарадњу у Летиойису Майище срииске, али и прибављање квалитетних литерарних прилога и придобијање талентованих писаца за сарадњу у овом часопису. Није занемарљив ни значај Дучићевих писама као докумената који омогућавају прецизније временско ситуирање догађаја из живота Јована Дучића - приређивач Дийломайских сйиса Јована Дучића, Миладин Милошевић изнео је тврдњу како је Дучић „У Рим (...) стигао почетком августа 1912. године...“9, док у дописници коју је послао Тихомиру Остојићу 30. августа 1912. године, Дучић експлицитно наводи: „Мили Тихомире, ако је Летопис с мојим есејом већ изишао, молим те пошаљи га у Рим, куда одлазим данас.“ (РОМС, инв. бр. 4. 914), тако да се Дучићев одлазак у Рим може, на основу ових писама, померити са почетка на крај августа 1912. године.

Дакле, писма и дописнице које је Јован Дучић послао Тихомиру Остојићу, у периоду од 1903. до 1914. године, из Швајцарске, Бугарске, Грчке и Италије сведоче о искреном и дугогодишњем пријатељству Јована Дучића и Тихомира Остојића; о лепој, продуктивној и непрекидној литерарној сарадњи двојице књижевника; ова писма и дописнице, уједно, садрже и Дучићеве аутопоетичке исказе; а као можда најважније од свега - писма и дописнице Јована Дучића пружају доказе о значају који преписка има у разумевању књижевних чињеница из (ближе и даље) прошлости, али и у процесу разумевања целокупне књижевне историје. Наиме, писма и дописнице Јована Дучића омогућили су прецизније и тачније разумевање начина на који је Јован Дучић био везан за Лейойис Майище срииске - иако је у овом часопису у време уређивања Тихомира Остојића Јован Дучић објавио

\footnotetext{
${ }^{8}$ Наведено према: Радован Поповић, Први поклисар - Јован Дучић, у: Жудња за фраком: срйски иичсии у gийломайији, Алтера, Београд, Задужбина Николај Тимченко, Лесковац, 2011, стр. 65.

${ }_{9}^{9}$ Миладин Милошевић, [Предговор], у: Јован Дучић, Дийломайски сйиси, приредио, предговор и коментаре написао Миладин Милошевић, Просвета, Београд, 1991, стр. 10.
} 
један једини текст, Дучић је био готово спољни члан редакције Лейойиса Майице срйске, неко ко коментарише уметничку вредност објављених прилога, неко ко се труди да пронађе сараднике, али и да мотивише писце да обављују прилоге у Остојићевом Лейойису, неко ко брине о техничкој страни часописа, али и аутор који је уреднику (Тихомиру Остојићу) обећавао да ће послати још текстова, што, међутим, није стигао да учини. Ипак, писма и дописнице које је Јован Дучић послао Тихомиру Остојићу расветљавају обим сарадње Јована Дучића у Летиойису Майице срйске у време уређивања Тихомира Остојића. Она показују у којој је мери Дучић био везан за Остојићев Летиойис, са колико је енергије и воље бринуо о „форми и стилу“ Летиойиса Майище срииске (а форма и стил елементи су који су били важни за Јована Дучића и као писца и као дипломату ${ }^{10}$ ), ова писма и дописнице, даље, доприносе изнијансиранијем и прецизнијем разумевању значаја који је Дучић придавао Летиойису Майище срйске (видећи себе као „посланство“ Летиойиса Майице срйске у Софији). Коначно, Дучићева писма и дописнице речито су сведочанство важности ишчитавања и познавања преписке српских писаца, као књижевноисторијског документа који омогућава тачније, продубљеније и свестраније разумевање историје српске књижевности (као и историје српске књижевне периодике).

\subsection{1}

Schnittweyer, den 11. Септ 1903 п. н.

Мили мој Тихомире,

Да ти се пријатељски јавим после пуне две године, али само са неколико речи. Хоћу само да те замолим да ми јавиш: јеси ли у Н. Саду и хоћеш ли бити вољан да ми даднеш нека објашњења, нека упуства, која се тичу само мене. У томе случају ја бих ти се јавио, одавде још, опширно, и изложио

10 Јован Дучић је записао: „Форма и стил чине књижевника, а то је потребно и дипломати да у страној држави задобије за своју домовину симпатије. Не могу државе које постављају књижевнике у дипломатску службу ништа тиме изгубити, него само добити.“ Ове Дучићеве реченице за мото „Предговора“ Дийломайским сйисима Јована Дучића изабрао је Миладин Милошевић. Видети: Миладин Милошевић, [Предговор], у: Јован Дучић, Дийломайски сийси, приредио, предговор и коментаре написао Миладин Милошевић, Просвета, Београд, 1991, стр. 7.

${ }^{11}$ Сва писма донета су онако како су написана, без исправљања грешака у правопису и интерпункцији. Очигледне словне грешке такође нису исправљане. Сегмент писма Јована Дучића од 22. новембра 1911. године (РОМС, инв. бр. 4. 917), који делује као засебна дописница, услед немогућности прецизног утврђивања датума и статуса тог сегмента писма, приређен је према инвентарском броју који му је додељен, а не према закључцима који се намећу из садржаја писма, о чему су читаоци ових писама обавештени из фусноте написане уз поменуто писмо. 
ти потанко у чему је ствар. Имао бих само једну изричну и пријатељску молбу: да о свему томе нико за сада не треба ништа да зна. Ствар је сама по себи врло наивне природе, али је у моме интересу да остане за сада позната само теби у чију дискретност и добру вољу према мени имам неограничено поверење.

Молим те јави ми се. Оно неколико сати проведених у друштву твоме и Радоњићевом, за ме су врло мила и свежа успомена, и то ми је дало повода да верујем да ћеш ми се и овом приликом јавити исто онако пун предусретљивости и љубазности.

Ја ћу овде у Алпима остати још коју недељу да завршим своју тромесечну куру и одавде враћам се поново за „ville-lumiere“, за Париз, на моју повољну (можда) годину на страни.

Пошто је ово писмо под дискрецијом, не шиљем овом приликом поздраве тамошњим пријатељима, него само теби и то топло и срдачно са пријатељским поштовањем

твој

Ј. Дучић

[РОМС, инв. бр. 4. 909; писмо $]^{12}$

22. нов. 1911

Софија

Драги мој Тихомире,

Имам једну пријатељску молбу.

Наш књижевник др Л. кнез Војновић који се својим несрећним стицајем прилика налази овде већ четири године, послао је Матици (Варађанин - Савић) један свој рукопис о земљотресу који је у 17-ом веку био уништио наш лепи Дубровник. Рукопис треба да се штампа у јануару.

\footnotetext{
12 На завршетку писма, у левом углу, Јован Дучић написао је: „Адреса: J. Doutchitch, Schnittwegerbad bei Thün (Suisse) Schwitz“.

13 Део овог писма који почиње речима „Мили Тихомире“, а завршава се речима: „Остајем овде до краја јула“, приређивачу ових писама делује као да није саставни део овог писма, већ пре као засебна дописница, чије би логичније датирање било јул 1912. године (после дописнице од 2. јула 1912. године. РОМС, инв. бр. 4. 911), након смрти Пенча Славејкова, којег Јован Дучић и помиње у писму и чије песме припрема заједно са опширним писмом. Ипак, иако се такав начин закључивања намеће као логичан, не могу се са сигурношћу утврдити ни датум ни статус (засебна дописница / саставни део писма) овог сегмента Дучићевог писма, стога се он приређује у затеченом стању, према библиотечком инвентарском броју који му је додељен, а не према садржају писма и информацијама садржаним у писму.
} 
Али како се дубровачком писцу јавила болест у кући која га огромно кошта, он је у овом тренутку у великој материјалној оскудици. Зато, знајући да сам пријатељ с новим секретаром Матице, молио ме да ти пишем и да те и у своје име замолим, ако икако можеш ${ }^{14}$, да му пошаљеш a conto 100 дин. то би га спасло од једне велике невоље.

Ја те молим да то учиниш. Он ће се одужити Матици за ту љубав. А и ja ћу се сматрати обвезаним. Ако можеш без седнице да то учиниш и да ми одмах телеграфираш да је ствар свршена, ја ћу за ту услугу да се, ако хоћеш, одужим Летопису прилогом чим ми то затражиш.

Дакле видиш колико правим апел на твоје пријатељство. Ово остаје међу нама, наравно.

Срдачно твој увек

J. Дучић ${ }^{15}$

Мили Тихомире,

Молим те пошаљи ми још два отиска оваква. Требају ми за отштампавање у засебну књигу.

Песме Славејкова спремам заједно с опширним писмом.

Молим те да слагач добро пази.

Срдачно твој

J. Дучић

P. S.

Остајем овде до краја јула.

[РОМС, инв. бр. 4. 917; писмо $]^{16}$

3.

10. IV. 912.

[Софија] ${ }^{17}$

Драги мој Тихомире,

нисам те заборавио, али на моје велико сажаљење нисам стигао да се ичим јавим твом Летопису. Али ако желиш да не сметнем с ума, и да поверујем да држиш до моје сарадње, шаљи ми Летопис. Нас нема много који

${ }^{14}$ Речи „,ако икако можеш“ Јован Дучић је подвукао.

15 На завршетку писма, у доњем левом углу Јован Дучић записао је адресу: „Адреса J. Doutchitch Attaché â la Légation de Serbie Sofia“, а ред испод ове реченице Дучић је написао „Телеграм: Doutchitch Légation Serbe Sofia“.

16 На полеђини писма Тихомир Остојић обичном оловком је записао „послао 6 дец. К 10071 Л. Војновић“ и „писао Дучићу 13 дец.“.

17 Јован Дучић не пише одакле шаље дописницу, али то се може закључити по поштанском жигу на којем пише „SOPHIA“. Такође, иако није наведена адреса, Јован Дучић је руком написао „Exp. J. D. Attaché â la Légalion de Serbie s.“ 
пишемо и који треба да буду заједно у Летопису, и зато лист мора чинити ту жртву - можда не и без свог интереса. Пошаљи ми свеске које су твоје.

Хтео сам да ти учиним један предлог о спољној страни. Стога сам поручио у [нечитка реч] једну свеску неке ревије чија је опрема угледна и вредна да се узме за образац. Некадашњи Летопис био је можда скуп али без укуса, и налик на све ценовнике семења, кољача, намештаја. Хоћеш да ти пишем о томе. Пошаљи свеске. Пријатељски увек твој

Ј. Дучић

[РОМС, инв. бр. 4. 915; писмо $]^{18}$

4.

25. V 1912

$\left[\right.$ Софија] ${ }^{19}$

Драги мој Тихомире,

За два три дана - чим будем све преписао начисто - добићеш мој рукопис. Шаљем ти један свој есеј (40 страна рукописа) о Петру Кочићу из књиге есеја који ће изићи до јесени. Надам се да ћеш бити задовољан.

Ја сам решен да ти будем од користи на Летопису. Надам се да ћу неке пријатеље задобити да узму Летопис као своје лично питање и обавезу. Одговори кад може изићи мој есеј. Могу ли стићи за ову свеску? Срдачно твој Ј. Дучић

[РОМС, инв. бр. 4. 912; дописница $]^{20}$

2 / VI. 1912

[Софија] ${ }^{21}$

Драги Тихомире,

Завршујем мој рад. Зашто ми не одговориш с две речи хоће ли стићи за прву наредну свеску.

18 Дрвеном бојицом плаве боје, на врху писма, Тихомир Остојић записао је датум када је на писмо одговорио „одг. 20/IV 3/V“.

19 Јован Дучић не пише одакле шаље дописницу, али то се може закључити по поштанском жигу на којем пише „SOPHIA“.

20 У горњем левом углу дописнице написано је: „Примих Летопис. Хвала.“ Дрвеном бојицом плаве боје Тихомир Остојић записао је када је одговорио „одгов 14 / VI“.

${ }^{21}$ Јован Дучић није забележио одакле је дописница послата, али на полеђини дописнице налази се поштански жиг на којем пише „SOPHIA“. 
Умро је Пенчо Славејков. Ја бих ти послао преводе (циклус) његових песама и некролог. Али треба да знам докле је дошла свеска која је у штампи и хоћу ли стићи за њу.

Одговарај, драги Тихомире.

Признаница нашег пријатеља одавна је у мене затурена у хартијама. Послаћу ти је заједно с рукописима. Али одговарај молим те. Срдачно твој увек

Дучић

[РОМС, инв. бр. 4. 911; дописница]

6.

$[1912]^{22}$

Драги мој Остојићу,

ево мој први рад за твој Летопис. Надам се да ћеш бити задовољан и уверен колико желим напретка твом листу. Ја сам ономад у Београду говорио с многим млађим добрим пријатељима да треба да Летопис сматрају својом ствари јер знам колико његов уредник ставља у њега амбиције, патриотизма и сујете.

Само, драги Тихомире, два мала услова:

1) да не изиђе рад на неугледном месту, и 2) да ја водим коректуру.

Осим тога молим те да ми, чим примиш рукопис пошаљеш хонорар.

Ја сам у овом тренутку заплетен у један непредвиђен трошак и морам створити што погоднију ситуацију за ове дане кад се знојимо и без тога. Скоро бих те молио да ми пошаљеш брзојавно ако не прелази 5 дин. трошка. Не треба да ти речем да ми пошаљеш цео хонорар, јер је питање о сваком динару. Сутра ћу ти послати и серију песама Пенча Славејкова у елегантној прози (јер ја сам против препевавања које увек убије оригинал својим врлинама или својим манама), а тако преводе и Енглези и Французи. Послаћу ти и биографију с оценом његове поезије. Тај чланчић би изишао ситнијим словима као Post scriptum тих превода.

Према томе одмери хонорар. Послаћу ти десет песама најлепших и најкарактеристичнијих за његов лепи таленат.

Опрости што овај есеј не послах пре. Ти не знаш каква сам цепидлака у писању и колико се порађам кад пишем само да се после не бих покајао за оно што кажем и како кажем.

22 Ово писмо Јована Дучића није датирано. Закључак о години када је послато може се извести из одговора Тихомира Остојића. Дрвеном бојицом плаве боје Тихомир Остојић написао је: „одгов 6 (19) јули 1912“. У каталошком листићу у Рукописном одељењу Матице српске за ово писмо Јована Дучића пише: „Софија, јуни, 1912.“ 
А сад: à toi la parole. ${ }^{23}$

Срдачно твој увек

J. Дучић

[РОМС, инв. бр. 4. 919; писмо]

7.

30. VIII. 1912

[Венеција] $^{24}$

Мили Тихомире,

ако је Летопис с мојим есејом већ изишао, молим те пошаљи га у Рим, куда одлазим данас. Прво што напишем биће опет за тебе. Срдачно твој, J. Дучић 25

[РОМС, инв. бр. 4. 914; дописница]

8.

4. IX 1913.

[Рим $]^{26}$

\section{Драги Тихомире,}

сутра ћеш добити један пакет рукописа за Летопис. Овим те молим само да ми одмах пошаљеш један број оног Летописа у којем је изишао лане мој есеј о Кочићу.

Срдачно твој увек

Дучић

[РОМС, инв. бр. 4. 918; дописница]

${ }^{23}$ Речи „,à toi la parole“ Јован Дучић је подвукао.

24 Јован Дучић не пише из којег места шаље ову дописницу, али да је у питању Венеција може се закључити по поштанском жигу на којем пише „VENEZIA“, као и на основу предње стране дописнице на којој се налази фотографија венецијанске лође и натпис „VENEZIA - La Loggetta“.

${ }^{25}$ На крају дописнице Јован Дучић написао је своју адресу у Риму: „Secretaire â la Légation de Serbie Rome“.

${ }^{26}$ Јован Дучић не пише одакле шаље ову дописницу, али то се може закључити на основу поштанског жига на којем пише „ROMA“, као и на основу фотографије сатира са предње стране дописнице и натписа „SATIRO - Prassitele M. Capit. Roma“. 
9.

10 септ. 1913

Драги Тихомире,

ево обећана рукописа. Писац је један млад Војвођанин с пуно књижевног смисла и књижевних способности. Ја сам га упутио да пише и надам се да ће скорим бити познат у нашој публици која тражи да се обнови наша критика у којој се октроишу принципи који би одвели натраг у детињство и неписменост. Из ове критике о гђци Исидори, која је писац првог реда, а која је наишла на једну заверу неинтелигентних, видећеш колико овај земљак уме да види и да каже.

Он докторира у [нечитка реч], а сад студира овде уметност по галеријама. Синовац је гђе А. Крсмановић, а родом из В. Бечкерека. Ја бих желио да он постане твој што редовнији сарадник. Писаће и друге ствари осим критике.

Мени је жао што нисам могао да ти пошаљем и неке своје ствари које сам ти наменуо. Овде сам са̂м отправник послова и једини представник Дарданије-Мезије-Илирије и Македоније код Цезара на Палатину. Али чим стигнем послаћу.

Нашем Манојловићу ако ти је икако могуће пошаљи 100 дин. на име хонорара за ове радове. Он спрема за другу свеску нове ствари. Овај чланак о маџарској лирици веома ће се свидети свима нашим писцима; веома су добри преводи песама Адијевих.

Пошаљи новац преко мене. Или брзојави ми па ћу му ја издати 100 динара. Он жели да крене за Напуљ и треба да му помогнемо.

Срдачно твој, драги Тихомире,

Ј. Дучић

P. S. Ја сам рукописе спремио за штампу.

[РОМС, инв. бр. 4. 910; писмо $]^{27}$

10.

4. дец. 1913

Драги Тихомире,

Примио сам „Летопис“ у којем са сажаљењем видим стихове скандалозног В. Илића Млађег и лепи приказ нашег Манојловића. Молим те лепо пошаљи ми онај хонорар који сам у твоје име дао Манојловићу чију сам ти признаницу послао. При крају смо године, кад закључујемо књиге. Пашић

${ }^{27}$ На трећој страни писма, у горњем углу, хемијском оловком црвене боје, Тихомир Остојић одговорио је: „Телеграфисао 27 / IX да Манојловићу да 100 дин.“ 
не би разумео да смо ми овде и посланство нашег Летописа. Извини што ти још ништа не шаљем. Ја сам са̂м. Али ћу стићи, надам се, за број који је на реду. Твој Ј. Д.

[РОМС, инв. бр. 4. 908; дописница]

11.

Athènes le 12 Јуни 1914.

\section{Драги Тихомире,}

Сада ти мене да аконтираш за 100 динара. Спремам ти један рад за Летопис, али ти нећу одмах моћи свршити јер сам овде у грдном послу (позван сам из Рима депешом). Морао сам да направим многе изванредне трошкове који су ме бацили у кризу, и сад сам остао без новаца. Молим те пошаљи ми одмах телеграмом ${ }^{28}$, и тиме ћеш ме неизмерно обвезати.

Чекам те, драги Тихомире, на белези

и срдачно поздрављам

твој Ј. Дучић

[РОМС, инв. бр. 4. 913; писмо]

12.

$[1914]^{29}$

[Софија ${ }^{30}$

Хвала, драги Тихомире, на брзом и лепом одговору. Идуће недеље послаћу ти обећано, и још рукопис једног пријатеља. - Зашто у овој свесци нема Вељка Петровића и Васе Стајића? Прока Јовкић није за Летопис. Обрати се Ћипику (Београд). Срдачно твој, Ј. Дучић

[PОМС, инв. бр. 4. 916; дописница] ${ }^{31}$

${ }^{28}$ Речи „одмах телеграмом“ Јован Дучић је подвукао.

${ }^{29}$ На дописници не пише датум када је послата. Из одговора Тихомира Остојића може се извршити приближно датирање. Наиме, дрвеном бојицом плаве боје Тихомир Остојић записао је „одгов 6 (19) / VII 1914“, тако да се са сигурношћу може утврдити да је Јован Дучић ову дописницу послао 1914. године, док се тачан датум не може одредити, иако се може претпоставити да је послата неколико дана или недељу дана пре одговора Тихомира Остојића.

${ }^{30} \mathrm{Hа} \mathrm{дописници} \mathrm{не} \mathrm{пише} \mathrm{из} \mathrm{којег} \mathrm{је} \mathrm{места} \mathrm{послата,} \mathrm{али} \mathrm{да} \mathrm{је} \mathrm{послата} \mathrm{из} \mathrm{Софије} \mathrm{може}$ се закључити по поштанском жигу на којем пише „СОФИЯ“.

${ }^{31}$ На предњој страни дописнице налазе се момак и девојка у бугарској народној ношњи, у горњем делу дописнице налази се натипс „Софийска селска носня“ и одмах испод њега „Costume des paysannes près de Sophia“. 
Милица В. Чукович

«МИССИЯ» ЛЕТОПИСИ МАТИЦЫ СЕРБСКОЙ В СОФИИ И РИМЕ: ПИСЬМА ЙОВАНА ДУЧИЧА ТИХОМИРУ ОСТОИЧУ

\author{
Резюме
}

В этой работе находятся собранные и прокоментированные письма и почтовые откритки, которые Йован Дучич отправил Тихомиру Остоичу от 1903 до 1914 года из Швейцарии, Италии, Греции и Болгарии. Эти письма и почтовые откритки, которые хранятся в Рукописном отделе Матицы сербской, свидетельствуют о многолетной, бесперерывной и красивой дружбе между Йованом Дучичем и Тихомиром Остоичем; они, дальше, содержат важные автопоэтические заявления Дучича (о пониманию перевода и свободного перевода стихов на сербский язык, а именно о природе собственного стиля), а больше всего, эти письма - свидетельство огромного труда, энергии, воли и хлопот, которые Йован Дучич (как внешний член редакции) вложил в Летопись Матицы сербской, когда редактором был Тихомир Остоич. Хотя в Летописи Матицыь сербской, во время редактирования Тихомира Остоича (с 1912 до 1914 года), Дучич опубликовал только один текст (эссе о Петре Кочиче), всё таки Дучич мотивировал писателей, чтобы они были сотрудниками Летописи Матииы сербской, собирал работы, даже заботился о техническом оборудованию журнала. Вот почему эти письма показывают сведение о связанности Йована Дучича и Летописи Матицы сербской, а ещё дают возможность исправить суд предыдущих изучателей о Йовану Дучичу, как сотруднику Летописи Матииьь сербской.

Институт за књижевност и уметност

Краља Милана 2, 11000 Београд, Република Србија

tiskicvet38@gmail.com 